\title{
EFFECTS OF FERTILIZATION ON QUALITY FLOWER PRODUCTION AND FOLIAR NUTRIENT CONTENT OF CARNATION (DIANTHUS CARYOPHYLLUS L.) CV. MASTER
}

\author{
Arvinder SingH*, BP Sharma, BS Dilta, Nomita Laishram, \\ YC GUPTA AND SK BHARDWAJ
}

\author{
Department of Floriculture and Landscaping, Dr. Y.S. Parmar University of Horticulture \\ and Forestry, Nauni, Solan, Himachal Pradesh-173 230
}

Key words: Carnation, Flower grades, Foliar NPK

\begin{abstract}
Carnation cv. Master plants fertilized with 250 ppm N and K fertigation through urea and MOP +250 ppm NPK foliar spray through a water soluble fertilizer Sujala (19:19:19 NPK) once a week is improved flowering as well as quality parameters and proved superior over the earlier recommended practices and the rest of the treatments.
\end{abstract}

Carnation (Dianthus caryophyllus Linn., Caryophyllaceae) is one of the most important commercial cut flower in the global florist trade owing to its excellent keeping quality, wide range of available colours and ability to withstand long distance transportation (El-Naggar 2009). Balanced fertilization is very essential for obtaining optimum plant growth and higher yield of good quality flowers. Fertigation is a noble approach that has gained importance nowadays due to availability of better quality water soluble fertilizers for commercial flower production in various greenhouse programmes. Subsequently, fertigation helps in uniform distribution besides better timings for more accurate and timely nutrition leading to better yield and quality and considerable savings in quantity of fertilizers to be used in comparison to conventional fertilizer applications (Bussi et al. 1991, Raina 2002, Raina et al. 2005). Plant response to foliar applied nutrients is a function of the amount of nutrients absorbed by the leaf tissues, the mobility of the nutrients within the plant and the phytotoxicity of the nutrients solution to the foliage. The largest potential benefit derived is when foliar nutrient applications are applied at the critical growth stages, specially when the nutrient requirement by the shoot is high (Garcia and Hanway 1976, Kanan 1980). Thus an ideal nutritional situation may be achieved through the promotion of plant growth by application of basal soil treatments in combination with foliar-applied nutrients. Carnation being a shallow rooted crop needs a regular supply of nutrients throughout its life cycle. It is well established fact that carnation plants make a good reserve of $\mathrm{N}$ at tufting stage which is utilized during flowering (Arora and Gill 1995). Keeping in view the felt need and importance of this crop, the present investigation was carried out with the objective to standardize a dose of conventional and water soluble fertilizers for quality flower production.

The experiment was laid out in CRD with 16 different treatments viz., $\mathrm{T}_{1}$ (Recommended practice i.e. basal doses of NPK @10g/ $\mathrm{m}^{2}$ each plus bio fertilizer mixture (VAM+ Azospirillum +PSM) @5g/plant applied at the time of planting. In addition to this, 100 ppm N (60 ppm through Multi-K and calcium nitrate, rest $40 \mathrm{ppm}$ ammonical nitrogen in the form of urea) and $140 \mathrm{ppm} \mathrm{K}$ (through Multi -K) twice a week after 40 days of planting ), $\mathrm{T}_{2}$ (75 ppm NPK fertigation through Sujala on alternate days in a week), $T_{3}\left(150 \mathrm{ppm}\right.$ NPK fertigation through Sujala twice a week), $\mathrm{T}_{4}$ (300 ppm NPK fertigation through Sujala once a week), $\mathrm{T}_{5}(100 \mathrm{ppm}$ NPK fertigation through

*Author for correspondence: <arvindersingh4601@yahoo.com>. 
Sujala on alternate days in a week), $\mathrm{T}_{6}$ (200 ppm NPK fertigation through Sujala twice a week), $\mathrm{T}_{7}$ (400 ppm NPK fertigation through Sujala once a week, $\mathrm{T}_{8}$ (125 ppm NPK fertigation through Sujala on alternate days in a week), $T_{9}(250 \mathrm{ppm}$ NPK fertigation through Sujala twice a week), $\mathrm{T}_{10}$ (500 ppm NPK fertigation through Sujala once a week), $\mathrm{T}_{11}$ (150 ppm N and K fertigation through Urea and MOP + 150 ppm NPK foliar spray through Sujala once a week), $\mathrm{T}_{12}$ (200 ppm N and K fertigation through Urea and MOP + 200 ppm NPK foliar spray through Sujala once a week), $\mathrm{T}_{13}(250 \mathrm{ppm} \mathrm{N}$ and $\mathrm{K}$ fertigation through Urea and MOP $+250 \mathrm{ppm}$ NPK foliar spray through Sujala once a week), $\mathrm{T}_{14}$ (150 ppm N and K fertigation through Urea and MOP + $150 \mathrm{ppm}$ NPK foliar spray through Sujala fortnightly), $\mathrm{T}_{15}(200 \mathrm{ppm} \mathrm{N}$ and $\mathrm{K}$ fertigation through Urea and MOP + 200 ppm NPK foliar spray through Sujala fortnightly), $T_{16}(250 \mathrm{ppm} \mathrm{N}$ and K fertigation through Urea and MOP + 250 ppm NPK foliar spray through Sujala fortnightly) replicated thrice. Rooted cuttings of carnation cv. 'Master' were planted in a sterilized growing medium consisting of soil: FYM: coco peat (2:1:1, v/v) on 9th of March, 2010 at a spacing of $20 \times 20 \mathrm{~cm}$ accommodating 25 plants per bed of $1 \mathrm{~m} \times 1 \mathrm{~m}$ dimensions. Standard cultural practices was followed during the entire cropping season.

Nutritional treatments were started after 40 days of planting and continued up to the bud formation stage (5 mm size). Foliar spray was done during morning hours (8.00 - 9.00 a.m.). Teepol $(0.05 \%)$ was used as a surfactant. The plots receiving foliar application were sprayed till runoff point $\left(2.5 \mathrm{l} / \mathrm{m}^{2}\right)$. Fertigation was done during evening hours. Each plot was fertigated with 5 litres of nutrient solution as per the treatment requirements. University recommended practice comprising of basal doses of NPK @10g/ $\mathrm{m}^{2}$ each + bio fertilizer mixture (VAM + azospirillum + PSM) @5 g/plant applied at the time of planting and 100 ppm N (60 ppm through Multi-K and calcium nitrate, rest $40 \mathrm{ppm}$ ammonical nitrogen in the form of urea) and $140 \mathrm{ppm} \mathrm{K}$ (through Multi-K) twice a week after 40 days of planting was taken as control.

To estimate stem quality on the basis of stem length, randomly 20 cut flower stems were selected per treatment and percentage of flowers of A, B and C grade was calculated as per the number of cut stems falling in each grade. A grade flowers consists of stem length with $55 \mathrm{~cm}$ and above, B grade having $43-54 \mathrm{~cm}$ and C grade with $30-42 \mathrm{~cm}$ stem length.

Leaf sampling for foliar NPK determination was done at peak flowering stage where leaves were taken from the fifth and six nodes from the apex. Total nitrogen content was estimated by Micro Kjeldahl method, potassium by flame-photometry and phosphorous was determined by Vanado-molybdate yellow colour method (Jackson 1973).

Data were subjected to statistical analysis of variance separately for each flowering flush. Pooled analysis of variance was performed to test the significant differences of different treatments as described by Gomez and Gomez (1984).

Lesser number of days to flower bud formation (102.18 days), first flowering (129.91 days) and harvesting stage (148.23 days) were recorded with the treatment $\mathrm{T}_{13}$ (Table 1). Maximum duration of flowering (23.17 days) was recorded with $\mathrm{T}_{13}$ and found to be at par with $\mathrm{T}_{12}$ whereas minimum duration of flowering (20.10 days) was recorded with $\mathrm{T}_{2}$. These results are in close conformity with the earlier findings of Pal and Biswas (2004) who reported longest duration of flowering with foliar application of $200 \mathrm{ppm} \mathrm{N}$ and P at fortnightly intervals in carnation cvs. 'Desio' (standard) and Super mix (spray). The maximum cut flower yield per plant (6.90) was obtained with $\mathrm{T}_{13}$ whereas minimum number of cut flowers (5.83) was obtained with control. Reduced leaching losses and improved fertilizer use efficiency through timely applications of N, P and $\mathrm{K}$ as a consequence of adequate soil moisture availability due to frequent fertigation might have led to increased photosynthetic rate. In addition foliar fertilization promoted better uptake of $\mathrm{N}, \mathrm{P}$ and $\mathrm{K}$ by the roots and hence resulted in higher utilization and translocation (Beaton and Espinosa 1996, Romheld and El-Fouly 1999). These results are in close conformity with the 


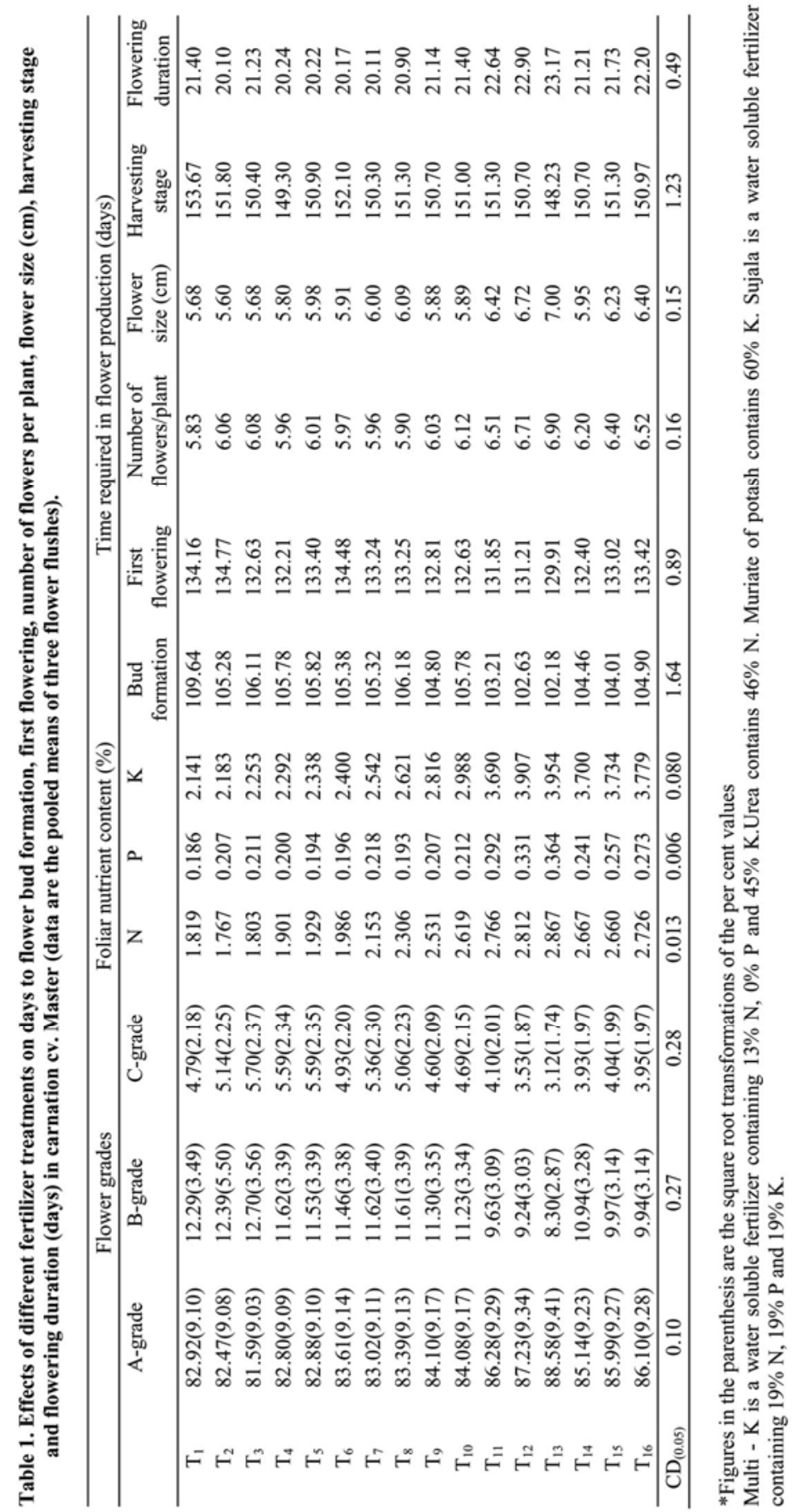


earlier findings of Ashok et al. (1999), Verma (2003) and Sarkar and Roychoudhary (2003) and El-Naggar (2009). The maximum flower size $(7.00 \mathrm{~cm})$ was recorded in treatment $\mathrm{T}_{13}$ whereas cut flowers of minimum size $(5.60 \mathrm{~cm})$ were recorded in $T_{2}$. The increase in flower size may be attributed to enhanced utilization and translocation of metabolites required for growth with increase in levels of applied N, P and K. These results get support from the findings of Verma (2003), Pal and Biswas (2005) Bhalla et al. (2007) and El-Naggar (2009) in carnation.

Foliar nitrogen content was recorded maximum (2.867\%) with the treatment $\mathrm{T}_{13}$ comprising $250 \mathrm{ppm} \mathrm{N}$ and K fertigation through urea and MOP + $250 \mathrm{ppm}$ NPK foliar spray through Sujala (19 : 19 : $19 \mathrm{NPK}$ ) once a week and minimum (1.767\%) with treatment $\mathrm{T}_{2}$. A comparison of data among different treatments indicates that the leaf $\mathrm{N}$ content increased proportionately with the increasing fertilizer doses. Similar findings have also been reported by El-Naggar (2009), Dufault et al. (1990), Nielson et al. (2002). Phosphorous content was recorded maximum (0.364\%) with $\mathrm{T}_{13}$ comprising $250 \mathrm{ppm} \mathrm{N}$ and $\mathrm{K}$ fertigation through urea and MOP + $250 \mathrm{ppm}$ NPK foliar spray through Sujala once a week and minimum (0.186) with $\mathrm{T}_{1}$ (Recommended practices). The results are in consonance with the findings of Verma et al. (2003), El-Naggar (2009), Qasim et al. (2008) and Dufault et al. (1990). Foliar potassium content was recorded maximum (3.954\%) with treatment $\mathrm{T}_{13}$ comprising $250 \mathrm{ppm} \mathrm{N}$ and $\mathrm{K}$ fertigation through urea and MOP $+25 \mathrm{ppm}$ NPK foliar spray through Sujala once a week and minimum (2.141\%) was recorded with treatment $\mathrm{T}_{1}$. These results get support from the findings of Verma (2003) who also reported increase in the K content of the leaves by the application of $1500 \mathrm{ppm} \mathrm{N}$ and minimum under control. Similar results were also reported by Ram and Bose (1994), Thombesi et al. (1962), Verma et al. (2003), Qasim et al. (2008) and El-Naggar (2009).

During the course of investigations, it was observed that treatment comprising of $250 \mathrm{ppm} \mathrm{N}$ and K fertigation through urea and MOP + 250 ppm NPK foliar spray through Sujala once a week $\left(\mathrm{T}_{13}\right)$ proved superior in recording maximum A-grade flowers based on stem length (88.58\%), respectively as compared to recommended practices or other treatments tested. Under fertigation, uniform distribution of the nutrients, coupled with confinement in the root zone, might have increased the nutrient uptake thereby leading to higher synthesis of metabolites and their subsequent translocation resulting in enhanced vegetative growth. Also the stimulatory effects of foliar application of higher doses of N, P and K might have resulted in better accumulation of assimilates thereby resulting in stronger and sturdier stems of A-grade cut flowers. These results are in conformity with the findings of Eck et al. (1961). Lindemann and Schwenker (1972), Medina (1992), Kowalczyk et al. (1992), Bhalla et al. (2007).

\section{References}

Arora JS and Gill APS 1995. Cultural requirements of carnation. In: Advances in Horticulture-Ornamental Plants (KL Chadha and SK Bhattacharjee. Eds.), pp.715. Malhotra Publishing House, New Delhi

Ashok AD, Arun D S and Rengasamy P 1999. Influence of graded levels and sources of $\mathrm{N}$ fertigation on flowering of cut rose cv. 'First Red' under protected conditions. South. Ind. Hort. 47(1/6): 115-118.

Beaton JDE and Espinosa J 1996. Fertigation and the use of liquid fertilizers X-Congreso Nacional Agronomico. pp.129-134.

Bhalla R, Shiva Kumar MH and Jain R 2007. Effect of organic manures and biofertilizers on growth and flowering in standard carnation (Dianthus caryophyllus Linn.). J. Orn. Hort. 10(4):229-23.

Dufault RJ, Phillips TL and Kelly JW. 1990. Nitrogen and potassium fertility and plant populations influence field production of gerbera. Hort. Sci. 25(12): 1599-1602.

Bussi C, Huguet JG and Defrance H. 1991. Fertilization scheduling in peach orchard under trickle irrigation. J. Hort. Sci. 66(4): 487-493. 
El- Naggar AH 2009. Response of Dianthus caryophyllus L. plants to foliar nutrition. World J. Agri. Sci. 5(5): 622-630.

Gomez LA and Gomez AA 1984. Statistical procedure for agricultural research. pp. 680. John Wiley and Sons Inc, New York.

Kowalczyk W, Marynowska M and Strojny Z 1992. Mineral nutrition of carnation cv. Tanga cultivated in heated plastic tunnels. Prace Instytutu Sadownictwa-i-Kwiaciarstwa-w-Skierniewicach Seria-b-Rosliny Ozdobne 17: 7-14.

Jackson ML. 1973. Soil chemical analysis. Prentice Hall of India. Pvt. Ltd., New Delhi. pp. 498.

Lindemann A and Schwenker KP 1972. Fertilizer trials after planting carnations. Deutsche-Gartnerborse 72(23): 504-506.

Medina TLA 1992. Study on the effect of some mineral nutrient deficiencies on greenhouse carnations (Dianthus caryophyllus) in hydroponic culture. Acta Hort. 307: 203-211.

Raina JN 2002. Drip irrigation and fertigation: Prospects and retrospects in temperate fruit production. In: Enhancement of temperate fruit production (KK Jindal and DR Gautam Eds.), pp. 296-301. UHF, Solan, Himachal Pradesh (H.P).

Raina JN, ThakurBC, Suman S and Spehia RS. 2005. Efect of fertigation through drip system on nitrogen dynamics, growth, yield and quality of apricot. Acta Hort. 696: 227-231.

RomheldV and El-Fouly MM 1999. Foliar nutrient application: Challenge and limits in crop production. Institut fur Pflanzenernahrung (330), Universitat Hohenheim, D70593, Stuttgart, Germany. pp. 1-25.

Sarkar I and Roychoudhury N 2003. Effect of nitrogen and phosphorus on growth and flowering of carnation cv. 'Chaubad Mixed' under open conditions. Environ. and Ecol. 21(3):696-698.

Nielson D, Neilson GH, Gauk S, Parchomchuk P and Hogue EJ. 2002. Management of water and nitrogen in high density apple orchards. The Compact Fruit Tree 35(3):92-96.

Garcia RL and Hanway JJ 1976. Foliar fertilization of soyabeans during seed filling period. Agron. J. 88: 653-657

Kannan S. 1980. Mechanism of foliar uptake of plant nutrients: accomplishments and prospects. J. Plant Nutrition 2: 717-73.

Verma VK, Sharma YD and Gupta YC 2003. Response of carnation to foliar application of nitrogen. J. Ornamen. Horticult. 6(2): 89-94.

Verma VK 2003. Response of foliar application of nitrogen and gibberellic acid on the growth and flowering of carnation (Dianthus caryophyllus L.). Himachal Journal. Agric. Res. 29(1-2): 59-64.

Qasim M, Ahmad I and Ahmad T. 2008. Optimizing fertigation frequency for Rosa hybrida l. Pakistan J. Bot. 40(2): 533-545.

Ram RA and Bose TK. 1994. Effect of foliar spray of urea and zinc on growth and flowering of mandarin orange (Citrus reticulata Blanco). Indian J. Hort. 51(3):266-271.

Thombesi LMT, Cale PB and Florelli E. 1962. Studies on the foliar diagnosis in the mineral nutrition of citrus. Prog. Agric. Bolonga 8: 1210-1225.

Eck P, Campbell FJ and Spelman AF 1961. Effect of nitrogen and potassium fertilizer treatment on soil concentrations and on production, quality and mineral composition of carnation. Proc. Amer. Soc. Hort. Sci. 80: 565-570.

Pal AK and Biswas B. 2004. Effect of pinching methods and fertilization on growth and flowering of standard and spray carnations under open field condition. Hort. J. 17(2): 175-180.

Pal AK and Biswas B 2005. Response of fertilizer on growth and yield of tuberose (Polianthes tuberosa L.) cv. Calcutta Single in the plains of West Bengal. Interacademicia 9(1): 33-36. 